\title{
Complete Kawasaki disease (KD) with peculiar skin manifestations
}

\author{
Dimitri Poddighe ${ }^{1,2}$
}

'U.O.C. Pediatria, ASST Melegnano e Martesana, Vizzolo Predabissi, Italy ${ }^{2}$ Dipartimento di Pediatria, Università degli Studi di Pavia, Pavia, Italy

\section{Correspondence to} Dr Dimitri Poddighe, dimimedpv@yahoo.it

Accepted 2 October 2017

\section{CrossMark}

To cite: Poddighe D. BMJ Case Rep Published Online First: [please include Day Month Year]. doi:10.1136/ bcr-2017-222724

\section{DESCRIPTION}

An 18-month-old female infant came to our medical attention because of persisting fever for 5 days. The child presented a diffuse and polymorphous skin rash having an angioedema-like aspect at the proximal parts of the limbs (figure 1). No drugs were taken before the admission.

The child was quite suffering, and the physical examination revealed some other remarkable signs: (1) non-purulent conjunctive injection; (2) cheilitis characterised with an intense lips redness, but no cracking (figure 2); (3) fingers and hands oedema, without palmar skin rash (figure 3). All these mucosal and cutaneous manifestations in addition to fever lasting longer than 5 days were consistent with the diagnosis of a complete form of Kawasaki disease (KD). ${ }^{1}$ Moreover, C-reactive protein and erythrocyte sedimentation rate were increased, as well as $\alpha 2$-globulin fraction of serum proteins.

As a consequence, the patient started the treatment with intravenous immunoglobulin at the standard dose of $2 \mathrm{~g} / \mathrm{kg}$ in $12-18$ hours, and she achieved a

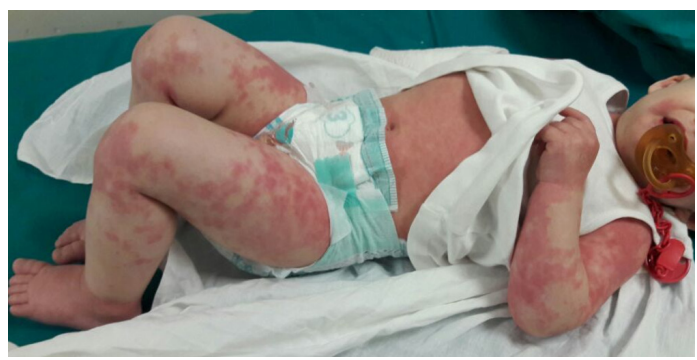

Figure 1 Non-specific polymorphous skin rash with urticarial and angioedema-like aspects.

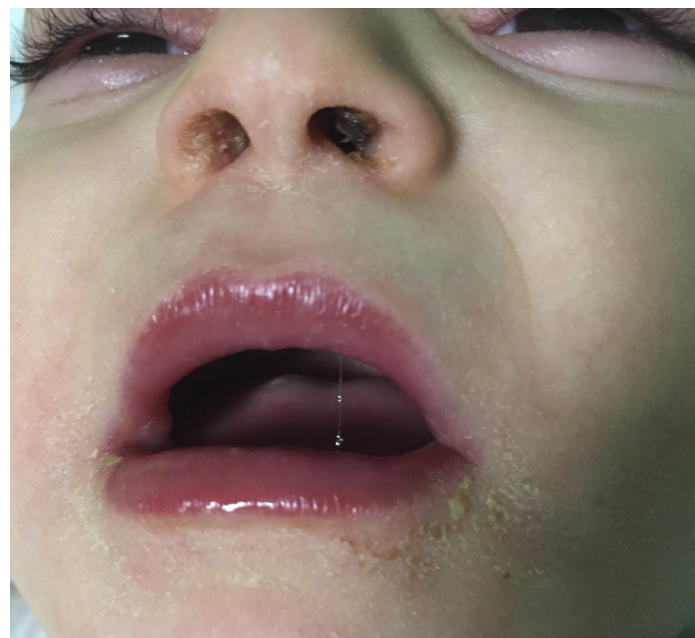

Figure 2 Cheilitis. complete and stable clinical response in 24-36 hours. High-dose aspirin $(80 \mathrm{mg} / \mathrm{kg})$ was used for 2-3 days, until the complete resolution of fever; thereafter,

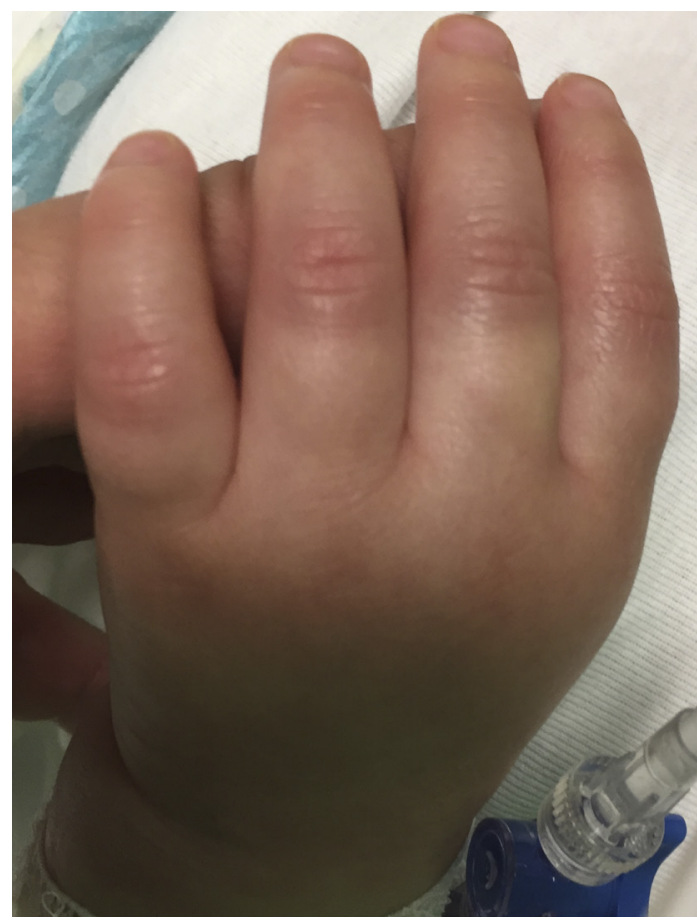

Figure 3 Fingers and hand oedema.

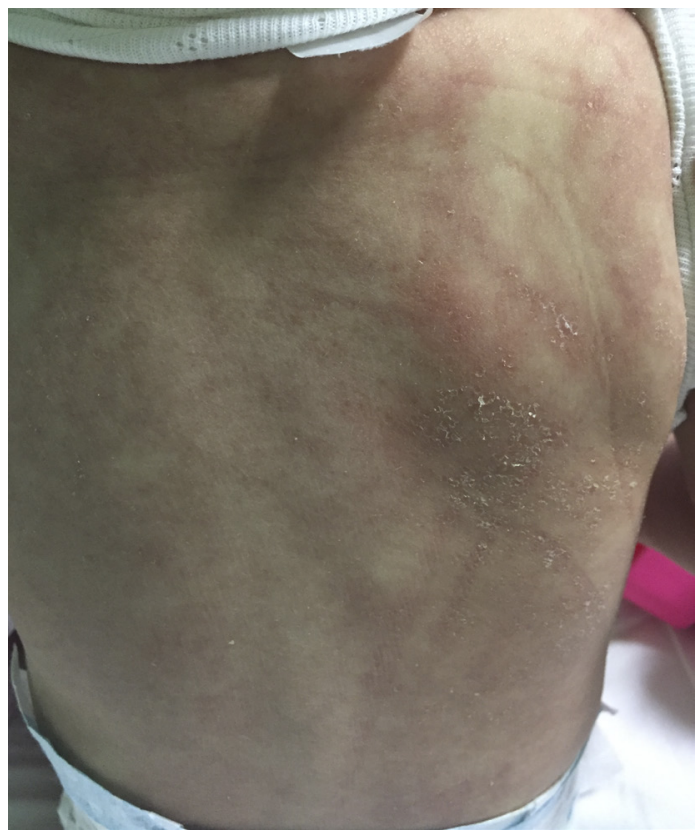

Figure 4 Skin desquamation after the amelioration of the rash. 


\section{Learning points}

KD rash can be quite variable: in addition to classic polymorphous exanthema, it can have multiple aspects, including urticarial and/or angioedema-like aspects.

- The careful evaluation of the association to other typicalbut non-specific — cutaneous and/or mucosal signs can lead to the diagnosis of KD.

low-dose aspirin $(5 \mathrm{mg} / \mathrm{kg})$ was started, as platelet count was increasing. No abnormalities of coronary arteries were detected through echocardiogram. On the sixth day following fever remission, the skin rash was markedly improved and started showing the typical desquamation at the trunk (figure 4).

The skin involvement during KD can be variable in type and extension. Initially, in this case, the skin rash showed some urticarial and angioedema aspects, which could have misled the diagnosis of KD. Indeed, the exanthema during KD is not specific and quite heterogeneous, and it can occur during several viral illnesses causing high-persistent fever (such as EBV, CMV and adenovirus, for instance) and important systemic inflammatory diseases. ${ }^{23}$ However, the association to other typicalbut non-specific-mucosal and skin manifestations of KD has correctly driven the diagnosis.

Competing interests None declared.

Patient consent Guardian consent obtained.

Provenance and peer review Not commissioned; externally peer reviewed. (C) BMJ Publishing Group Ltd (unless otherwise stated in the text of the article) 2017. All rights reserved. No commercial use is permitted unless otherwise expressly granted.

\section{REFERENCES}

1 Dietz SM, van Stijn D, Burgner D, et al. Dissecting Kawasaki disease: a state-of-the-art review. Eur J Pediatr 2017;176:995-1009.

2 Poddighe D, De Amici M, Marseglia GL. Spontaneous (autoimmune) chronic urticaria in children: current evidences, diagnostic pitfalls and therapeutic management. Recent Pat Inflamm Allergy Drug Discov 2016;10(1):34-39.

3 Poddighe D, Cavagna L, Brazzelli V, et al. A hyper-ferritinemia syndrome evolving in recurrent macrophage activation syndrome, as an onset of amyopathic juvenile dermatomyositis: a challenging clinical case in light of the current diagnostic criteria. Autoimmun Rev 2014;13(11):1142-1148.

Copyright 2017 BMJ Publishing Group. All rights reserved. For permission to reuse any of this content visit http://group.bmj.com/group/rights-licensing/permissions.

BMJ Case Report Fellows may re-use this article for personal use and teaching without any further permission.

Become a Fellow of BMJ Case Reports today and you can:

- Submit as many cases as you like

- Enjoy fast sympathetic peer review and rapid publication of accepted articles

- Access all the published articles

- Re-use any of the published material for personal use and teaching without further permission

For information on Institutional Fellowships contact consortiasales@bmjgroup.com

Visit casereports.bmj.com for more articles like this and to become a Fellow 